\title{
Feminist Mining: A Step towards Sustainable Mining in India
}

\section{Feministyczne górnictwo: krok w kierunku zrównoważonego górnictwa w Indiach}

\section{Priya Singh*, Ajit Kumar Behura**}

\author{
Indian Institute of Technology(ISM), Department of Humanities and Social Sciences, \\ Dhanbad-826004, India \\ *E-mail: priya.deepak1701@gmail.com,ORCID:0000-0003-3394-9709 \\ **E-mail: ajitbehura@gmail.com
}

\begin{abstract}
Economic growth and development with least harm to the environment is one of the biggest challenges for the human. Mining which is considered to be the most inherently unsustainable industry, is at the same time, plays key role in the development process in India and across Globe. It occupy primary position in the supply chain, contributing to the foreign direct investment, exports, government taxes, GDP (National Income) and provide huge labour employment.

This paper studies industrial elimination of women, prolong industrial patriarchy, impetuous production, rising demand pressure has added to the quadrupling problems of land degradation, disposal of over burden/waste discharge, deforestation, pollution(air, water, and noise), and damage to forest flora and fauna, occupational health hazards and extreme global environmental damage in a rapid, continuous manner. These continuous and multilayered problems are giving us reason to re-visioning steps, where we went wrong.

Theoretical foundation of eco-feminism traces that negligence and suppression of women in general and in the mining industry, is one of the probable cause that hit environment fiercely. With this in mind, this paper suggests theory of eco-feminism into male centric mining industry as a perspective which is more likely to lead to industrial sustainability, making it more responsible and may provide pro-environmental solutions to the industry. This feminist concept extending it from individualistic level into mining organisations proposes as one of the alternative to combine ecology and commerce to envision sustainability.
\end{abstract}

Key words: sustainability, ecology, environmental degradation, feminism, economic development

\section{Streszczenie}

Wzrost gospodarczy i rozwój przy jak najmniejszej szkodliwości dla środowiska to jedno z największych wyzwań dla człowieka. Górnictwo, które jest uważane za najbardziej z natury niezrównoważony przemyst, odgrywa jednocześnie kluczową rolę w procesie rozwoju w Indiach i na całym świecie. Zajmuje podstawową pozycję w łańcuchu dostaw, przyczyniając się do bezpośrednich inwestycji zagranicznych, eksportu, podatków rządowych, wzrostu PKB (Dochodu Narodowego) i zapewnia ogromne zatrudnienie.

Ten artykuł bada przemysłową eliminację kobiet, przedłużanie patriarchatu przemysłowego, gwałtowną produkcję, rosnącą presję popytową, która przyczyniła się do problemów degradacji gruntów, usuwania nadmiernego obciążenia / odprowadzania odpadów, wylesiania, zanieczyszczenia (powietrza, wody i hałasu) oraz szkód flory i fauny leśnej, zagrożeń dla zdrowia w miejscu pracy i ekstremalnych globalnych szkód środowiskowych w szybki i ciągły sposób. Te ciągłe i wielowarstwowe problemy dają nam powód do rewizji działań, w których popełniliśmy błędy.

Teoretyczne podstawy ekofeminizmu dowodzą, że zaniedbania i represje wobec kobiet w ogólności i w górnictwie są jedną z prawdopodobnych przyczyn działań, które mocno uderzają w środowisko. Mając to na uwadze, niniej- 
szy artykuł przedstawia teorię eko-feminizmu w przemyśle wydobywczym zorientowanym na mężczyzn jako perspektywę, która z większym prawdopodobieństwem doprowadzi do zrównoważonego rozwoju przemysłu, czyniąc go bardziej odpowiedzialnym i może zapewnić prośrodowiskowe rozwiązania. Ta feministyczna koncepcja, rozszerzająca ją z poziomu indywidualistycznego na organizacje górnicze, proponuje jako jedną z alternatyw połączenie ekologii i handlu w celu osiągnięcia zrównoważonego rozwoju.

Slowa kluczowe: zrównoważoność, ekologia, degradacja środowiska, feminizm, rozwój ekonomiczny

\section{Introduction}

Mining is about all the processes involved in extraction of any kind of minerals from earth (surface or beneath). Mining encompasses exploration of nonrenewable resources from the earth crust including seas in gaseous, solid and liquid forms, subsequent processing, recapturing by-products for their domestic, industrial and commercial purposes playing important role in human development and business over decades (Sigam and Garcia, 2012). The history of Mining or digging and extraction in India dates back to the early Harappa Civilization. The country (India) is endowed with wide variety of the minerals and a major contributor to economic growth and development. Mining sector is one of the key driver's for economic growth, employment generation and synergies other core industries like power, steel, locomotive, fertilizer, cement, etc (Kirsch, 2010).

Mining in India has changed its phase and pace over decades. Histories have shown that, mining was done to sustain livelihoods, very conventional and as forms of artisanal. From private, artisanal and small scale mining to colonisation and organised on nationalisation further diversified across nation on globalisation (Chauhan, 2010; Lahiri-Dutt, 2018). The advent of technology, mechanisation, social perspectives attached with industry such as strength, dark, protectiveness and regulatory framework in the forms of Acts are the major drivers for not only change but also shaping mining industry as malecentric industry. Characterised by masculinity, power, domination with a motive of profits guided by industrialisation (1970's) and globalisation (1991) promoted aggressive and speedy extraction of minerals in India (Lahiri-Dutt, 2011).

This dominating trends of production, consumption are deeply interlocked with gender inequitable relationships that headed generations towards deeply unsustainable directions (Bradshaw, 2019). Leaving behind traditional economic developmental processes, in the lust and confidence of patriarchy, opportunistic rush or influx towards the mining rich land, ease of extraction, lack of standardised production regimes has become a matter of Indian mining shock in the forms of growing nexus of illegal mining, resource overuse, neither proper mine closure plan nor its implementation, commodity price fluctuations, conflict between industry and society or local communities, unexpected closure of commercial mines; fines; penalties, etc. (Mohanty and Goyal 2012; Syed Maqbool Geelani, Bhat S.J.A., 2013). As mining activities are increasing in volume and variety, strong and multi-layered negative pressure on environment brings problem of sustainability (Kirsch, 2010).

Sustainability means development and wellbeing of current generation, nature, economy as well as maintaining the same for our future generations (Azapagic, 2004; Abrahamsson et al., 2014; Vintró et al., 2014). Sustainability is the ability to maintain and develop its triple bottom line dimensions altogether that is economic, social and environment. With all three dimensions are having different perspective, Social dimensions speaks about human rights and holistic participation of community including men and women both. Sustainability cannot be achieved without holistic participation of half of the India's population in each and every aspect. Linking gender equality with sustainable development is one of the key agendas of sustainable developmental goals and it is also important as moral and ethical imperative (Bradshaw, 2019). In the mining industry, sustainability aims to minimize the environmental impacts which are inherent to this activity (Gomes et al., 2014; Onn and Woodley, 2014). Therefore, in order to achieve long-term sustainability of one of the most polluting industry i.e. Mining industries, its current functioning, decision making mechanism (which is highly masculine brains) are needs to be reassessed by feminist approaches in order to make them more ethical towards environment and society.

Eco-feminism is about establishing bonds between feminism and environmentalism. Eco-feminism argues that the exploitation and limited participation of women and the degradation of the environment are consequences of patriarchy and capitalism (Shiva, 1988; Waring and Steinem, 1988). Eco-feminism proposes that only by overturning current values(mostly patriarchal), imbibing care, nurture and incorporating cooperation over aggressive and dominating behaviours, can benefit society and environment as well (Buckingham, 2015). The detailed perspectives such as biological, social, ideological are thoroughly explored that establishes closer links between women with nature. The Eco-Feminism principle and there under attributes of care and nurture nature can be used as a remedy towards environmental destruction. Considerable evidences from different sectors from all over the world recognising that women generally expresses different concerns than men with regards to environmental problem's (Ergas and York, 2012) and are more pro-environmental 
and provides better environmental solutions. Evidences from organisations/industries and nations are taken where women proved and gave outstanding performances when provided positions with power and concern for environmental protection (Bradshaw, 2019).

\section{Mining Industry, Society and Development: Lit- erature Review}

\section{A) Indian Mining Industry}

Over the ages, mining industry has evolved gradually as primary sector after agriculture becoming essential for livelihood and survival of human being. Mining is playing vital role in the process of modern economic development and socio-cultural changes. India has considerable domestic reserves of minerals. India ranks 5 th in the top 20 (Non-UN Countries) ranked on production value of metallic mineral and coal and India scores 56th rank (out of 182 non-UN Countries) on its mineral resources (Index, 2018). Particularly, in India, the mining and quarrying sector's contribution (at current price) to GVA (Gross Value Addition) accounted for about $2.38 \%$ for the year 2018-19.The estimated average daily employment of labour engaged in mining sector (excluding atomic and minor minerals) was 4,77,399 in 201718. India produces almost 95 types of minerals and ranks leading mineral producing country for the valuable minerals such as Chromite, Barytes, Coal and Lignite, Bauxite, Iron-Ore, Steel, Zinc, Copper, Manganese, etc (Mines, 2019). Government of India through its various ministries like Ministry of Mines, Ministry of Coal, and Ministry of petroleum and Natural Gas is responsible for directing the entire minerals and mining sector in the country that includes legislation, administration, policy formulation etc. Legislation governing and controlling the mining sector through various regulatory frameworks such as The Mines Act 1952, Mines and Mineral (Development and Regulation) Act 1957, The Minerals Concession Rules, 1960, The Mineral Conservation and Development Rules 2017, Etc.

\section{B) Society and Industrial Development}

The very first mining was evolved out of the efforts in search of stone for making weapons for hunting and tools. Primary stone tools are approximately 2.6 million years old, predating even Homo Sapiens around 1.9 million years ago. Mining and usage of metals majorly gold, silver, copper and gemstones have been done extensively during the Pre-Vedic period i.e. (circa 400-1600 B.C.). The artisans of preHarappa (Circa 4000-2000 B.C.) and Harappa-Mohenjo-Daro-Indus valley (Circa 3000-1500 B.C.) civilizations used stones, chemicals like soda, lime and gypsum and alloys of copper, bronze for building and other developmental purposes. Yet, mining and usage of coal and steel was unknown prior to 1777. However, the word Angara (derived from
Agni) is used as a meaning fuel, occurs in several places. The Yajurveda (1100-1000 B.C.) mentions copper, gold, silver, lead, tin and iron specially, but it is also significant to note that the Vedic Sage'susedto dig the earth in search of Agni. Arthashastra (400 B.C.), written by Chanakya (Kautilya), give most primitive and authentic records of minerals (Khanija) and the industrial mining (Scholz, 2017). Similar descriptions of metals and metallurgy in medicine have been described in Charka and Susruta Samhitas (1200-400 BC) (Mahesha, 2011). During Ashoka's empire stone inscriptions depicts usage of steel and its various forms during 4th century BC. From the records of great historians and global travellers like Megasthenes (c.300 B.C.) Pliny (AD77), Fa Hien (5th Century), Huen Tsang (7th Century), Al Beruni (11th Century), Travernier (1665-69) several information on mining, usage and trade of steel, its alloys and gemstones over ages were found in India (Vajda, 1976). The evolution of mining parallels to the history of civilization and so many important cultural eras have been named and associated after various minerals or their By-products: the Stone Age (prior to 4000 B.C.E), the Bronze Age (4000 to 5000 B.C.E), the Iron Age (1500 B.C.E to 1780 C.E.) the Steel Age (1780 to 1945), and the Nuclear Age (1945 to the present)(Lahiri-Dutt, 2011). However, in India, first aluminium industry was set-up in 1808, it was in the year 1774 for coal mines and 1777 for iron ore, when first time permission was accorded by Warren Hastings for actual mining of coal and iron ores. Although, not much attention was given at that time due to coal's poor quality, higher cost involved in its extraction and other political reasons, which laid so much delay to the process of industrialisation, but the very start-ups may be seen as the fuel for industrial revolution in India.

\section{Environmental Degradation}

Mining in India plagued with several environmental socio economic problems. There are multi-level, direct and indirect, short-term and long term negative impacts associated with mining. It is like we are moving forward, outperforming economically but we are getting closer towards our own extinction. The ecological, social sufferings in terms of diseases, pollution, and unequal distribution of wealth will be too high that our future generations would not enjoy the very fruits of development. Every steps involved in proposed mining plan is adding multi-level degradation to the environment and society at large (Ritsema, 2002; Kirsch, 2010; Worldwide, 2010; Pimentel et al., 2016). This phase of proposed mining plan is applicable mainly to the extraction of ore deposits such as iron, zinc, coal etc.

Exploration \& Prospecting: This stage deals with geophysical identification of mineral from earth 
crust, followed by drilling to evaluate minerals according to purpose. This phase includes field surveys, studies, drilling, boreholes and other exploratory excavations. This exploratory phase involve huge clearing of area's vegetation, disturbing faunas, use of heavy machineries, drilling rigs, creates noise and air pollution in addition. This exploration is done in core ecological balanced areas thus sensitizing flora, fauna and surrounding population.

Development \& Design: A model design for the ore body is developed which includes methods and technology requirements to assess the commercial feasibility of the mine. Construction of approach roads, clearance of vegetation, and removal of overburden. This also involves key observation, technological, chemical exploration of underdeveloped area having reserves.

Mine Construction: This phase deals with reaching to the ore or mineral by the use of technology i.e. either open caste or underground mine. This is done by exploitation, land clearances, geographical modification of land, rehabilitation and resettlement. This also impact land, water, noise, air pollution and ecological imbalance.

Production: This phase is the longest in the overall life of mine which ends for more than 10 to 40 years or even more. This phase involves actual mining and extraction of minerals or ores. This is the phase which adds to highest negative impact not only to nearby area but globally. This has multiplying environmental impact.

Closure: This phase represents end of the life of a mine and end of mining processes. This stage is as critical as it involves long term degradation impacts. The left-out or completed mines have higher chances of collapse, water flooding, overall geographical change of the land forms, chemical leaks and changing form that pollute ground water quality and air pollution, abandoned mines are un-rehabilitated.

Post-closure: After closing its reclamation, restoration and rehabilitation stage, in which efforts are made to reduce the negative footprints by ecological restoration, which is very nascent concept in India. It is generally ignored which lead to overall environmental degradation, pollution, etc.

In totality, Mining activities causes physical, chemical, biological and socio-economic changes in the area such as soil pollution and change in the landscape of the area, drainage of acid waste in water, mercury and lead contamination in water, loss of flora-fauna and other biotic life forms, rehabilitation, resettlement of population are the first hand problems (Chauhan, 2010; Mohanty and Goyal, 2012; Syed Maqbool Geelani).
The level of degradation by its inherent nature, whose negative impact can be mitigated by following traditional/subsistence/need based method of mining by human. Yet, Men as breadwinners, considered dominant breeds and are major drivers of change (mechanisation, scientific revolution, industrialisation, etc.) focuses on major transformation of society and economy contributing to the most pressing ecological and social problems of our day much earlier causing natural death of ecology (Merchant, 2006). For example, Rapid and Populous rehabilitation and relocation of natives arises as direct outcome of mining, who are close to nature not only causes social change but also poses to the challenges of loss of livelihood, loss of their subsistence thus food insecurity, mental and physical health problems(Ahmad and Lahiri-Dutt, 2006). It has become a prolonged arena which has been dominated by men and one where masculine practices and discourses were common from the boards (policy formulation) or in exploration or in extraction processes of nature as wild and in need of discipline and control. These irresponsible mining practices with priority on production and safety rather than environmental concerns impact and compromise our communities, our health and environment and affect deeply and specifically women in multiple ways.

\section{Journey from Mining to Prejudice Mining: Com- plete Patriarchy}

Women labour and utilization of services of women is as old as our Indus civilization about 3000 B.C. Histories also agrees that women were found shouldering men in almost all the occupations of life (Kaur, 1987).Yet, Labour history is mainly about men, and gender history is usually about Women (Van Goethem, 2006). Studies in general shows that our labour history was gendered; the positions held by her, the inter and intra sector environment, culture and treatments received from their counterparts were almost gendered as systems of domination or systems of inequality that both diverged and converged (Boris et al., 1999). Industrial societies are organised on the basis of gender i.e. Men are workers, women are mothers' (Brush, 1999). Although much about participation of women in the labour market could not be found out in recorded form, but women have played a critical role in mining industry. Records, mostly oral histories, have revealed that in early mines, men and women laboured together (Gier and Mercier, 2006). Typically, they were labourers (e.g. shale pickers, manual coal loaders, paners, ore carriers), goods and services provider (e.g. cooks, shopkeepers) and often solely responsible for their domestic duties. In extractive industries, women were mainly involved in the supporting mining activities ranging from crushing, grinding, churning, collecting ores, washing and panning, to amalgamation in 


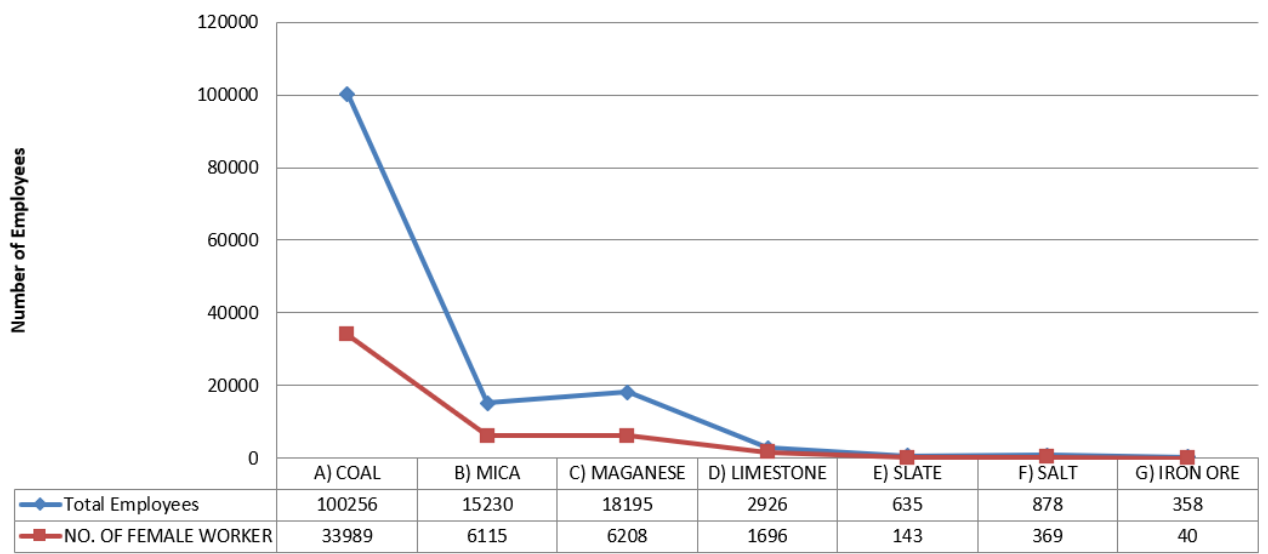

Figure 1. Average Number of female deployed daily in the mines majorly coal, mica, manganese, salt, slate, during 1907, source:(Wilson, 1907)

the specific gold mines (Hinton et al., 2003). The period and aftermath of World War I provide glimpses of women active participation of women in the labour market. One of the major reason could be the war that lead to massive death of soldiers(male) and scarcity in manpower in the labour market. The same brought women into active employment in metal industry, particularly, arms industry during the war, that broke the hegemony of men in industrial labour. As post-war period was a crucial period towards identifying and securing rights of labourers in general, this period was very much important for emergence of women workers representations in the form of initiatives to stand, argue and defend for their rights, equality, took initiatives to participate in policy formulation, etc on various platforms, globally. They actively participated in first International Labour Conference to represent their rights equally from almost 83 countries, show their energy and will to work in mining industry (Zieger, 2010). Thus, it may be inferred that, Mining sector as primary sector after agriculture has given equal opportunity to both male and female to participate actively for their survival and livelihood. The essence of industry in shaping our everyday life and economy is well recognised by literature. While talking about organised/structured mining labour force in Indian Mining industry, during the year 1907 the average number of persons working in and about mines regulated by the Indian Mines Act, was 151,983, of whom 98,824 worked underground and 53,159 on the surface; 96,769 were males, 49,116 were females and 6,098 children under 12 years of age.

The numbers shows women were deployed sufficiently in different mines in India. Another researcher conducted investigation in three principal coal fields in India are in Jharia, Raniganj and the Central Provinces having altogether 885 mines, in which over 263000 persons were employed out of the total labour force in 1944, roughly a quarter were women (Deshpande, 1946). Some studies also found that women played major role in Indian artisanal mining (Hilson, 2002; Lahiri-Dutt, 2006). It can be seen from records that unorganised Mines pre-post nationalisation involves $70 \%$ of female workforce. Africa deploys highest number of female artisanal miners ranging to $40-50 \%$ while in some other regions the percentage raised even to 60 to $100 \%$ women (Amutabi and Lutta-Mukhebi, 2001; Onuh, 2002). In west African countries and villages of Nigeria, Kenya women were dominant and exclusively employed in salt mining (Onuh, 2002).

Later on with rise in labour laws, protection of human rights specifically women and children, safety, increasing cases of harassment/exploitation of women, distinguish on the basis of physical ability lead to deteriorating female numbers. Differences in wage payment on the basis of gender, disparity in access of getting education and employment, mechanisation, transformation from subsistence economy to commercialisation added to this (Lahiri-Dutt, 2007). Several studies says that mining is having traits of masculinity and extractive industries ended up with only deployment of male (Mercier, 2011). Post-colonization, as the processes of globalisation expanded, mining has grown as more masculine (Mayes and Pini, 2010). Transition from $18^{\text {th }}$ to $19^{\text {th }}$ century was a historic turmoil for all people and industries across world. The great depression, decolonization, end of World War-I were the prominent junctures for all nation. During that phase, the conditions and sentiments of labour, social justice and humanity were recognised as prominent factors for establishing universal peace (Zieger, 2010). Thus, in 1919, International Labour Organisation (ILO) was constituted, as a specialised agency for providing recommendations, developing conventions protecting rights of labours and developing labour standards in the matters such as: Hours of working of a labour, Prohibition of women and child during night time, Minimum age for entering into mines, Welfare facilities, etc.

Accordingly, India while coming out of colonisation, inspired by the conventions of ILO and Mining regulations existing for British India mines by lord Cross, 1890, shaped their first Mines Act 1952 which 


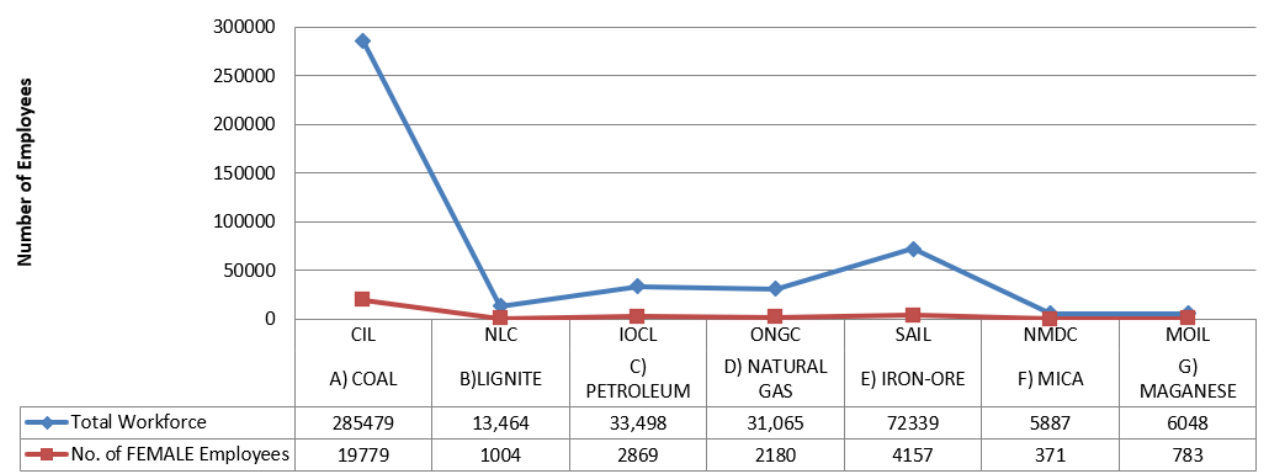

Figure 2. Average number of Female employee by big Mining Giants in the Year 2019, source (CIL; IOCL, 2019; MOIL, 2019; NLC, 2019; NMDC, 2019; ONGC, 2019; SAIL, 2019).

came into force from 01.07.1952 (Udayakumara, 2008; Lahiri-Dutt, 2012, 2019; DGMS, 2020).

Rule 46 of Mines Act, 1952 prohibits employment of women in the terms that no women shall be employed below ground in any part of mine and above ground only limiting hours i.e. between 6 a.m. to 7 p.m. (Lahiri-Dutt, 2012; Sudhamani, 2017). Limiting the hours of women work deprives women from the opportunity to work in shifts, which are strictly applicable in large organised mines with better wages. It is found that gender exclusions emerged at uniform particular historical moments across the world (Gier and Mercier 2006). This perception was even enforced by series of mining countries such as British Mines act of 1842, Germans in 1878, North America in 1890 Sweden in 1900, Russia in 1917, Japan in 1933 (Sudhamani, 2017; Lahiri-Dutt, 2019). It is found that workplaces, especially mines, were not and still are not gender-neutral locations (Schilt and Connell, 2007).The impact of such changes were so deep and strong that even in 2019, the average number of female deployment in mining industry has deteriorated to meagre $6-7 \%$ by big business giant.

\section{Struggle for Sustainability Mining: An Indian Scenario}

As India is among one of top ten countries in minerals reserves, there is no other choice in resources than mining, that contribute to nation's development. Thus the controversies of 20th century have been shifted towards reducing detrimental imprints through sustainable mining. Sustainable development have become a bustle word in natural resources especially non-renewable resources as their stock is limited and their attached environmental problems. India has formulated number of policies, laws, rules and regulations over years for mining industries striving towards sustainability. Looking the mining scenario, conflicts around and loopholes attached lead to time to time amendments, modification, addons in the several acts such as Environment Protection (Amendment) Act (EPA, 2006), New Mineral Policy (2008), etc. provisions under regulatory-leg- islative mining framework for environmental protection. India is known to be among one of the country that flooded with acts and its rulings. Yet, the industry is facing challenges of sustainability due to long and bureaucratic system of getting approvals, sometimes duality in control between state and central and most common is the governance failure in administration of minerals (Mohanty and Goyal, 2012). Deployment of advanced technological solutions(such as hydraulic mining by replacing hand held drills with hydraulic and jumbo drills), Public disclosure on sensitive issues like sustainability, transparency, community participation, internal audits by the individual big companies, ISO (International Organizations for Standardization) certifications such as 14001 - for managing, assessing environment , audit reports by the Comptroller and $\mathrm{Au}-$ ditor General (CAG), EIA (Environmental Impact Assessment) have lead path towards sustainable mining. There is still lots of challenges, like the existing and rising social dissatisfaction, local conflicts and unrest, gherao by locals, non-conformities and ignorance, long pending and pertinacious resettlement issues, limited community development as a mere compliances require a more closer view, proenvironmental, long term feasible deliberation and introspection by changing perspective of the industry (Pressend et al., 1995).

\section{Prospect of Sustainable Mining}

A Theoretical Analysis through Ecofeminism: establishment of deep connection between nature and women.

Women images and roles are keep changing over era's; since mythology to contemporary, depending on the male dominance, circumstances, social needs and others. One of the concepts aroused out of environmental problems such as rising level of pollution, climate change during 1980, at the end of World War-II, when the participation of women towards protecting environment and their ecological restoration concerns were recognised across globe and termed as eco-feminism. Some highly recognised women laid movements in India are like Chipko 
Movement during 1970, Ecological movement by the Bishnois, anti-arrack movement in Andhra Pradesh are the major drivers for conceptualising ecofeminism.

The term ecofeminism was first reckoned by Francoise D'Eaubonne (A French feminist) with a concept that women's oppression and the destruction of nature have the same origin: the patriarchal perspective, which exerts control and power over both and reason for their subjugation. She tries to establish deep connections between women and environment and patriarchy as the reason for all global environmental problems. The new perspective of ecofeminism was much talked, recognised that women's rights and environmental rights cannot be left altogether and its practical impact towards survival and recreation of mother earth was felt during end of 90’s.

\section{Biological roots}

This perspective conceptualises as Nature creates lifeforms and made efforts for possible survivals. Likewise women also give birth to new lives on earth and make all possible efforts towards caring, nurturing, development of lives. These motherhood traits of care, nurture, softness towards nurturing is a common base for establishing deep connection between women and nature. Motherhood Effect increases environmental concern for women (Blocker and Eckberg, 1989; Greenbaum, 1995; Davidson and Freudenburg, 1996). Mother's moral responsibility of care and concern for their child and family initiated their active participation in movements that they perceive as an environmental threats (Nelkin, 1981; Levine, 1982; Hamilton, 1985). Organismic theory viewed earth as a nurturing female, lay at the centre of a cosmology in which nature and society were dynamically interconnected (Leach 2007).

\section{Social roots}

Beyond reproductive roles, histories have shown that how men went outside in order search for food, haunting, involved in rapid war whereas women restricted themselves with collecting dry leaves, fallen woods, collecting water and managing with nearby resources for fulfilling needs of their family (Hoskins, 1982; Rocheleau, 1991; Agarwal, 1992). It was found that difference in the intensions of men and women towards same environment (Leach, 2007). Moreover likewise earth which makes our survival on earth possible, women are creators of live forms. So virtues of care, nurture, balance, management, social adjustments and finding substitute in scarcity are imbibed by their mere acts performed, in day today affairs. Such practices based on requirements of life also gave them deep and extensive knowledge and experiential expertise, more than men (Dankelman, 1989). Moreover, women are con- sidered towards rebuilding ecological cycles and ones that will ensure and nurture planet health (Köhler-Rollefson, 2018). The suggestion that women are involved in community managing work undertaken anywhere to everywhere from urban and rural contexts as well (Moser, 1989).

\section{Ideological roots: psychic structure}

Ecofeminism is a concept that maintains connectivity and togetherness between human and non-humans without dissolving individual's subsistence in conceptual terms also. It establishes integral relationships between self and other directly to the nature, thus maintains interdependence and autonomy (Mathews, 1994). It is all about equality not domination, it may be towards women, men or nature(Gaard and Gruen, 1993). It was well established that women and nature are used as a means to satisfy goals of patriarchy. Ecofeminists believe that human beings are not separate from nature but they are a part of the natural world (Jackson, 1993). Thus, the concept of Eco-feminists considers that all life on earth is intertwined with each other. Ecosystems are likely to benefit different domains of men's and women's wellbeing differently, some researcher says that women emphasised relational aspects of wellbeing(Abunge et al., 2013). It is perceived by some authors that biological, physiological and neurological differences between male and female results their significant thinking differences, their emotional quotients, behaviour pattern and thought process. Women in general are attributed towards higher into wellbeing domains, emphasising on household consumption over commercial/sales, plant use and gatherers, custodian of seeds, etc. (Reyes-García et al., 2010; Yang et al., 2018).

\section{Reinvestigating role of women in Mining and Feminist Mining}

Indian history of minerals is very old and rhetoric towards building and shaping strong nation's. However, mining industry development is very nascent in terms of inculcating better ethical practices, gender parity in specific. After various exploitation under colonialism and turmoil like world war, Indian mineral industries brought the concept of CPSE's (Central Public Sector Enterprises) and PSU's (Public Sector Enterprises), wherein control of exploration and exploitation of majority of minerals rests with the central and state government with a view of welfare balance of society over profitability. The very purpose and spirit of these enterprises (good practices defined by the equality of opportunities) dissolved then and there as the industry prohibited and restricted employment of women.

Despite females played major role in building civilizations, studies have shown the same vulnerable stature of women in mines in India and around the globe. 
This Women's status plight is not natural and is not due to biological differences rather it is created by social, cultural, historical and economic factors. Previous research have explored few majorly identified factors like sexual exploitation and harassment, gender-power relations, difficulties balancing family and work responsibilities, responsibility towards reproductive roles, social norms surrounding female workers, education, traditionally male/hard/masculine associations to mining, etc. (Yount, 1991; Pattenden, 1998; Gibson and Scoble, 2004). In extractive industries, women role is largely under-recognised, under-theorised and under-investigated (Jenkins, 2014). It is found that, there are no physiological reasons as to why women cannot perform the same tasks as men, only if they wish to do it. In $\mathrm{Si}$ erra Leone, many interviewees noted that mining is wrongly considered as physical/masculine activity assigned solely for men (Rickard et al., 2017). Early histories of organised mining and artisanal mining in India also depicts that women have worked alongside men equally sharing loads for livelihood even in mining industry (Hove and Hlongwana, 2015).

For India, it took long way almost 70 years to understand the gendered division of mining industry. As per Gazette Notification No. 393 ( S.O. 506(E)) dated 29 January 2019, the Central Government exempted the deployment of women above or below ground (any mine)from the provisions of Section 46 of the Mines Act, 1952, subject to certain conditions, namely:-

(a) For employing women in any open cast mines, i.e. above ground:

The restrictions on engaging women between $7 \mathrm{pm}$ to 6 am in any mines on surface(open-cast) is waivedoff seeking written consent from the concerned female employee with not less 3 women in a single shift. While on duty, every female should be provided sufficient facilities and safety, security at workplace. The Standard Operating Procedure (SOP) shall be framed and implemented on the basis of guidelines of Chief Inspector of Mines, beforehand for engaging women.

(b) The restrictions on employing women in any underground mines is waived-off by allowing women employment underground with limiting hours i.e. between 6 am and 7 pm in any type of technical, supervisory and managerial work where continuous presence may not be required, keeping other clauses same as detailed for open cast female engagements. This amendment in the Mines Act, 1952 is not just a mere change in Act but can be recognised as breakthrough in stereotyped mining by providing opportunity, acting ethically towards sustainable development, taking into rights, dignity and capabilities of other half of the world's population (Ministry of labor and employment, 2019).

Today's scenario, Mining as a discipline is not only concerned with Mining/Extraction rather to holistic mines plan which require visionary thought process, permits, clearances, persuasion, empathetic view towards community. Women with more emotional outlook towards their environment, community, family, friends will always take decisions prioritising such considerations and are more prosperous in long term (Ward, 2010; Bauhardt, 2014; Spectrum, 2018). Thus this is a new thought process with shiftin-masculinity, which means changing old, partial, masculine mind-set and new consensus to the mining industry. For example: Some researcher establishes that integrating women will develop better community relations and will drive production with innovation and redefine development through empowering women (Ahmad and Lahiri-Dutt, 2006; Rickard et al., 2017). Another example is the group of women in Ayacucho refused to sign an agreement with a company for Tambogrande would not be developed as a mine because they said that they could see no overall benefit for their community in doing so (Ward, 2010).

The preponderance of women in mining will enable the primary caregivers to bring their individual feminist traits like care, nurturing, balance, multi-tasking, etc to organisational level that will be a remodelling of mining practices facilitating holistic change into the overall culture and functioning of an organisation including financial performances, productivity, profitability, improve corporate governance, lower cost of finance, reduce corporate fraud, etc (Yang et al., 2018).

Although, women are employed in mining sector but their number is very less that to limited to peripherical jobs. However, by increasing their participation in core Mining and Administrative roles as well, will provide a double check system in itself. In one way, at administrative and decision making policy-front, they check policy formulation and if there is any ignorance or unforeseen harm, female at technical front while performing actual mining work will check in ecological prospects at the time of actual mining.

This concept does not view gender equity as essential to economic change but infusing feminist traits into every aspect of mining industry through increasing participation of women. Women-men smart partnerships in mining produce more gains than when the two sexes operate in homogeneous syndicates (Hove and Hlongwana, 2015) infuses new and different perspectives to patriarchy mining.

Globally, women are recognised as relatively untapped sources of skill, energy and on the job talents (Mihail, 2006). Realising the same globally other countries pro-actively changed their workforce pattern, emphasised on gender equality. It has been argued at large by researchers that women are pre-occupied by their home responsibility, care of family and children, gender- defined responsibilities (Salinas and Romaní, 2014). However, it can be seen as an opportunity that it takes at least half of work life to get board level positions that makes around 
age group of 45 and above. At this age of life, where women are more or less free with their basic family responsibility, at this juncture, women can take leap of faith to proof their worth in such a critical industry. Years of experience will give advantage in shaping their pro-environmental vision. It is only their early carriers that need to be taken care of by facilitating them by providing crèches at workplace, firstaid, rest rooms, health and hygiene, toiletries, etc.

Women will not just understand mining but they will apply their virtuous soft skills into mining, empathise with environment, people in order to make it economically viable. It is said that $4 \mathrm{Ms}$ of production: Man, Machine, Material and Money, Human is the most challenging factors to handle. Women reports to experiencing higher emotions than men across the life span. Women reports greater overall warmth, emotional expressiveness and concern for other than do men (Grossman and Wood, 1993). Several studies have shown that female participation, saves cost of corporate by taking better care of equipment in a responsible way, follow safety protocols, work more safely (IFC, 2013). For example: In Mexican Mining Industry, women participation is accessed highly beneficial in terms of their loyalty, responsibility, careful and protective attitudes towards self and machinery, less oblivious.

Thus, increasing presence of women will be helpful towards changing practices and attitude that will lead the inherently unsustainable mining towards sustainable mining in a better way. It is imperative from histories that women do things different than men and are better planners because they do not only think of present given situation but also plan for next and work accordingly. Be it planning at work or household works, Studies have also shown women can perform multiple task at a time in a better way, however men can only focus on limited things at a time, difficulty in switching jobs frequently and reaction time is also fast in men (Sayer, 2007; Mayes and Pini, 2010; Offer and Schneider, 2011; Stoet et al., 2013).

\section{Conclusion}

The study assessed the extent of participation of women and gendered nature of Indian mines. Available evidence indicates that neither industry nor biologically women were discriminated rather it is society and their different protective, male centric and dominant arguments that shaped mining as only male industry. This paper has established that industrial patriarchy brought masculine characteristics into industry in the form of aggressive mining, harsh expansion decision, pursuit of progress and profit figures with least environmental concern brought environmental degradation beyond its threshold limit. The mining by its inherently polluting nature and adding to this patriarchy industrial enterprises supported by Government regulatory framework took least concern, careless attitudes towards environment and nature brought us much earlier at an alarming stage to the multiple environmental, social, individual problems. The oppression of women within the socio-cultural context and flagrant environmental changes are further theorised in this paper as ecofeminism may be used to restore and nurture nature. We have reinvestigated how participation of women into core mining beyond peripherical works and accepting, bringing feministic traits in every aspect of mining will be a sustainable move to the male tradition and prolonged old age practices of mining. In light of these findings the paper recommends that the formation of gender inclusive cooperatives as one of the priority in mining industry, raising the participation of more women at all the level will go beyond the empowerment of women, bringing social parity and most likely to step-up sustainability in the sector considering ecology and mining trade management together.

\section{References}

1. ABRAHAMSSON L., SEGERSTEDT E., NYGREN M., ET AL., 2014, Mining and Sustainable Development: Gender, Diversity and Work Conditions in Mining, Luleå tekniska universitet.

2. ABUNGE C., COULTHARD S., DAW TM., 2013, Connecting marine ecosystem services to human well-being: insights from participatory well-being assessment in Kenya, Ambio, 42: 1010-1021.

3. AGARWAL B., 1992, The gender and environment debate: Lessons from India, Fem Stud, 18:119-158.

4. AHMAD N., LAHIRI-DUTT K., 2006, Engendering mining communities: examining the missing gender concerns in coal mining displacement and rehabilitation in India, Gend Technol Dev 10: 313339.

5. AMUTABI M., LUTTA-MUKHEBI M., 2001, Gender and mining in Kenya: The case of Mukibira mines in Vihiga District, Jenda a J Cult African women Stud, 1.

6. AZAPAGIC A., 2004, Developing a framework for sustainable development indicators for the mining and minerals industry, J Clean Prod, 12: 639-662.

7. BAUHARDT C., 2014, Solutions to the crisis? The Green New Deal, Degrowth, and the Solidarity Economy: Alternatives to the capitalist growth economy from an ecofeminist economics perspective, Ecol Econ, 102: 60-68.

8. BLOCKER T., ECKBERG D., 1989, Environmental issues as women's issues: General concerns and local hazards, Soc Sci $Q$, 70: 586.

9. BORIS E., JANSSENS A., JANSSENS A., 1999, Complicating categories: gender, class, race and ethnicity, Cambridge University Press.

10. BRADSHAW S., 2019, Sustainability and Gender Equality: Exploring the 2030 Agenda for Sustainable Development. In: Environment and Sustainability in a Globalizing World, Routledge: 232-245.

11. BRUSH L., 1999, Gender, work, who cares?! Production, reproduction, deindustrialization, and business as usual, Revis Gend, 161-189.

12. BUCKINGHAM S., 2015, Ecofeminism. 
13. CHAUHAN S.S., 2010, Mining, development and environment: a case study of Bijolia mining area in Rajasthan, India, J Hum Ecol, 31: 65-72.

14. CIL Annual Reports and Accounts, 2018-19, Kolkata.

15. DANKELMAN J., 1989, Women and the Environment in the Third World, Routledge, London, U.K.

16. DAVIDSON D.J., FREUDENBURG W.R., 1996, Gender and environmental risk concerns: A review and analysis of available research, Environ Behav, 28: 302-339.

17. DESHPANDE S.R.,1946, Report on an Enquiry into Conditions of Labour in the Coal Mining Industry in India.

18. DGMS, 2020, The History, http://dgms.gov.in/User View/index?mid=1396 (14.05.2020).

19. ERGAS C., YORK R., 2012, Women's status and carbon dioxide emissions: A quantitative crossnational analysis, Soc Sci Res, 41: 965-976.

20. GAARD G., GRUEN L., 1993, Ecofeminism: Toward global justice and planetary health, Soc Nat, 2: 1-35.

21. GIBSON G., SCOBLE M., 2004, 'Regendernering' the mining industry A survey of women's career experiences in mining, CIM Bull, 54-59.

22. GIER J., MERCIER L., 2006, Mining women: Gender in the development of a global industry, 1670 to 2005, Springer.

23. GOMES C., KNEIPP J., KRUGLIANSKAS I., et al., 2014, Management for sustainability in companies of the mining sector: an analysis of the main factors related with the business performance, J Clean Prod, 84: 84-93.

24. GREENBAUM A.,1995, Taking stock of two decades of research on the social bases of environmental concern, Environ Sociol Theory Pract: $125-152$.

25. GROSSMAN M., WOOD W., 1993, Sex differences in intensity of emotional experience: a social role interpretation, J Pers Soc Psychol, 65: 1010.

26. HAMILTON L., 1985, Concern about toxic wastes: Three demographic predictors, Sociol Perspect, 28 : 463-486.

27. HILSON G., 2002, Small-scale mining and its socioeconomic impact in developing countries, Natural Resources Forum, Wiley Online Library: 3-13.

28. HINTON J., VEIGA M., BEINHOFF C., 2003, Women and artisanal mining: gender roles and the road ahead. socio-economic impacts Artis smallscale, Min Dev Ctries: 149-188.

29. HOSKINS M., 1982, Social forestry in West Africa: myths and realities, Department of Sociology, Virginia Tech.

30. HOVE E., HLONGWANA J., 2015, A step into the male dominated mining sector: Women's participation in mining: the case of Kwekwe District, Zimbabwe, J Humanit Soc Sci, 20: 99-104.

31. IFC, 2013, Investing in Women's Employment, Washington.

32. ILO Underground Work (Women) Convention, 1935, (No. 45), https://www.ilo.org/dyn/normlex/en/f?p= NORMLEXPUB:12100:0::NO::P12100_ILO_COD E:C045 (1.05.2020).

33. INDEX MC., 2018, Role of mining in national economies.

34. IOCL, 2019, Annual Report.
35. JACKSON C., 1993, Doing what comes naturally? Women and environment in development, World Dev, 21: 1947-1963.

36. JENKINS K., 2014, Women, mining and development: An emerging research agenda, Extr Ind Soc, 1: 329-339.

37. KAUR P., 1987, Woman labour in India a socio legal study, Panjab University.

38. KIRSCH S., 2010, Sustainable mining, Dialect Anthropol, 34: 87-93.

39. KÖHLER-ROLLEFSON I., 2018, Purdah, purse and patriarchy: The position of women in the Raika shepherd community in Rajasthan (India), J Arid Environ, 149: 30-39.

40. LAHIRI-DUTT K., 2018, Between the Plough and the Pick: Informal, Artisanal and Small-scale Mining in the Contemporary World, ANU Press, Australia.

41. LAHIRI-DUTT K., 2011, The megaproject of mining: A feminist critique, Engineering earth, Springer: 329-351.

42. LAHIRI-DUTT K., 2006, Gendered Livelihoods in Small Mines and Quarries in India: Living on the edge, Rajiv Gandhi Institute for Contemporary Studies Canberra, Australia.

43. LAHIRI-DUTT K., 2007, Roles and status of women in extractive industries in India: Making a place for a gender-sensitive mining development, Soc Change, 37: 37-64.

44. LAHIRI-DUTT K., 2012, The shifting gender of coal: Feminist musings on women's work in Indian collieries, South Asia J South Asia Stud, 35: 456-476, DOI: 10.1080/00856401.2011.633984.

45. LAHIRI-DUTT K., 2019, The act that shaped the gender of industrial mining: Unintended impacts of the British mines act of 1842 on women's status in the industry.

46. LEACH M., 2007, Earth mother myths and other ecofeminist fables: How a strategic notion rose and fell, Dev Change, 38: 67-85.

47. LEVINE A., 1982, Love Canal: Science, politics, and people.

48. MAHESHA A., 2011, Environmental degradation in the context of modernization a study of rural Karnataka, Bangalore University.

49. MATHEWS F., 1994, Relating to nature: Deep ecology or ecofeminism? The Trumpeter.

50. MAYES R., PINI B., 2010, The 'feminine revolution in mining': A critique, Aust Geogr, 41: 233-245.

51. MERCHANT C., 2006, The scientific revolution and the death of nature

52. MERCIER L., 2011, Bordering on equality: Women miners in North America, Gendering $F$ Towar Sustain, 33 .

53. MIHAIL D., 2006, Gender-based stereotypes in the workplace: the case of Greece, Equal Oppor Int.

54. MININSTRY OF MINES, 2019, Annual Report.

55. MINISTRY OF LABOR AND EMPLOYMENT, 2019, Now Equal Employment Opportunities for Women in Mines, Press Inf. Bur., https://pib. gov.in/newsite/PrintRelease.aspx?relid=187977.

56. MOHANTY N., GOYAL A., 2012, Sustainable Development: emerging issues in India's mineral sector. Res Study.

57. MOIL, 2019, Annual Report 2018-19.

58. MOSER C., 1989, Gender planning in the Third World: meeting practical and strategic gender needs, World Dev, 17: 1799-1825. 
59. NELKIN D., 1981, Nuclear power as a feminist issue, Environment, 23(1)

60. NLC, 2019, Annual Report.

61. NMDC, 2019, Annual Report 2018-19.

62. OFFER S., SCHNEIDER B., 2011, Revisiting the gender gap in time-use patterns: Multitasking and well-being among mothers and fathers in dual-earner families, Am Sociol Rev, 76: 809-833.

63. ONGC, 2019, Annual Report 2018-19.

64. ONN A.H., WOODLEY A., 2014, A discourse analysis on how the sustainability agenda is defined within the mining industry, J Clean Prod, 84: 116127.

65. ONUH B., 2002, Salt Women of Keana.

66. PATTENDEN C., 1998, Women in Mining: A Report to the 'Women in Mining' Taskforce, the Australasian Institute of Mining and Metallurgy. Australasian Institute of Mining and Metallurgy.

67. PIMENTEL B., GONZALEZ E., BARBOSA G., 2016, Decision-support models for sustainable mining networks: fundamentals and challenges, $J$ Clean Prod.

68. PRESSEND M., MTHETHWA D., HLABANE M., MARA I., 1995, Breaking communication barriers between communities affected by mining and the mining industry in South Africa, Agenda, 21:2.

69. REYES-GARCÍA V., VILA S., ACEITUNO-MATA L. et al., 2010, Gendered homegardens: a study in three mountain areas of the Iberian Peninsula, Econ Bot, 64: 235-247.

70. RICKARD S., TREASURE W., MCQUILKEN J. et al., 2017, Women in mining: Can a mining law unlock the potential of women.

71. RITSEMA IL., 2002, Asset life-cycle in the mining industry: Deposit and Geoenvironmental Models for Resource Exploitation and Environmental Security. Springer, pp 277-290.

ROCHELEAU D.E., 1991, Gender, ecology, and the science of survival: Stories and lessons from Kenya, Agric Human Values, 8: 156-165.

72. SAIL, 2019, Annual Report 2018-19.

73. SALINAS P., ROMANÍ G., 2014, Gender barriers in Chilean mining: a strategic management, Acad Rev Latinoam Adm.

74. SAYER LC., 2007, Gender differences in the relationship between long employee hours and multitasking, Res Sociol Work, 17: 403.

75. SCHILT K., CONNELL C., 2007, Do workplace gender transitions make gender trouble?, Gender, Work Organ, 14: 596-618.

76. SCHOLZ T., 2017, Artisanal and Small-Scale Mining. Mining in the Asia-Pacific, Springer: 271283.
77. SHIVA V., 1988, Staying alive: Women, ecology and survival in India, Kali for Women.

78. SIGAM C., GARCIA L., 2012, Extractive industries: Optimizing value retention in host countries, UNCTAD New York and Geneva.

79. SPECTRUM, 2018, Women and EIA processes, Myanmar.

80. STOET G., O'CONNOR DB., CONNER M., LAWS KR., 2013, Are women better than men at multitasking?, BMC Psychol, 1: 18.

81. SUDHAMANI P.M., 2017, A critical study into the Implementation of ilo conventions pertaining To the working conditions of women workers in India with special reference to the selected Industrial establishment in Karnataka, Karnatak University.

82. SYED M.G., BHAT S.J.A. SHG, 2013, mining and its impacts on environment with special reference to India, Int J Curr Res, 5: 3586-3589.

83. UDAYAKUMARA R., 2008, Aspects of flexibility in the implementation of international labour standards in India, Jawaharlal Nehru University.

84. VAJDA S., 1976, Introduction to Minimax, $J R$ Stat Soc Ser A, 139: 276.

85. VAN G. G., 2006, An international experiment of women workers: The International Federation of Working Women, 1919-1924, Rev belge Philol d'histoire, 84: 1025-1047.

86. VINTRÓ C., SANMIQUEL L., FREIJO M., 2014, Environmental sustainability in the mining sector: evidence from Catalan companies, J Clean Prod, 84: 155-163.

87. WARD B., 2010, Gender-sensitive approaches for the extractive industry in Peru: improving the impact on women in poverty and their families, The World Bank.

88. WARING M., STEINEM G., 1988, If women counted: A new feminist economics, Harper \& Row San Francisco.

89. 35. WILSON J.R.R., 1907, Report of the Chief Inspector of mines in India, Calcutta.

90. WORLDWIDE ELA., 2010, Guidebook for evaluating mining project EIAs, Eugene, OR Environ Law Alliance Worldw.

91. YANG S., LIU Y., MAI Q., 2018, Is the quality of female auditors really better? Evidence based on the Chinese A-share market, China J Account Res, 11: 325-350.

92. 93. YOUNT K., 1991, Ladies, flirts, and tomboys: Strategies for managing sexual harassment in an underground coal mine, J Contemp Ethnogr, 19: 396422.

93. ZIEGER R., 2010, The ILO and the Quest for Social Justice, 1919-2009. 